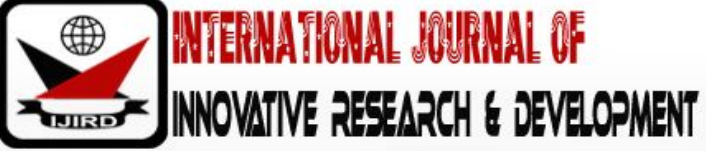

ISSN 2278 - 0211 (Online)

\section{Market Based Monetary Policy Instruments and Industrial Growth in Nigeria (1993-2016)}

\author{
Dr. Ayodeji Emmanuel Abiodun \\ Senior Lecturer, Department of Banking and Finance, Afe Babalola University, Nigeria \\ Ajala Rosemary Bukola \\ Senior Instructor, Department of Banking and Finance, the Federal Polytechnic, Ekiti State, Nigeria
}

\begin{abstract}
:
This study was initiated to investigate the effects of market-based monetary policy instruments on industrial growth in Nigeria, covering a period beginning from 1993 to 2016. Upon the threshold of the traditional Keynesian IS-LM model, and the employment of auto-regressive distributed lag model with vector auto-regression impulse response function, the study found a long-run relationship between market-based monetary policy instruments and industrial growth in Nigeria: for, industrial growth significantly responded to own innovations and impulses from all the three market-based monetary policy instruments. And monetary policy rate accounted for the largest variation in industrial growth; however, the second largest variation was initially accounted for by open market operation, but was finally accounted for by legal reserve requirement. It was, therefore, concluded that, market-based monetary policy instruments have significant effects on industrial growth in Nigeria, and it was recommended that, the central government should follow monetary policy initiatives that would stimulate industrial growth in Nigeria, as this has a greater tendency to engender economic growth and development in the country.
\end{abstract}

Keywords: Monetary policy, market-based instruments, industrial growth

\section{Introduction}

Monetary policy is the economic policy of the central government, which is used in influencing the level of economic activities of a country through the adoption of monetary measures, such as open market operation, monetary policy rate, cash reserve requirement, special deposits, credit ceiling, and sectorial credit allocation, among others. These monetary measures or instruments are technically referred to as instrumental variables. Monetary policy is aimed at achieving economic stabilization, growth and sustainable development; these are the ultimate targets of monetary policy, and are technically referred to as target variables. Thus, instrumental variables are manipulated by the central authority to influence and control the level of economic activities for the achievement of the target variables, that is, the ultimate goals of monetary policy.

The Central Bank of Nigeria [CBN] Monetary Policy Framework (2011) classified the instrumental variables into direct and indirect monetary policy instruments. This Framework, otherwise, refers the indirect instruments as marketbased instruments. Following the aforementioned order of classification, Owolabi and Adegbite (2014) noted that, the Nigerian monetary policy has moved from the era of direct to indirect instruments of monetary management. The direct instruments are the monetary policy instruments adopted to control and restrict the use of money or credit in an economy. These instruments include credit ceiling, sectorial credit allocation, stabilization securities, interest rates control, imposition of special deposits, and moral suasion. The indirect instruments are the monetary policy instruments employed to control the total quantity of money in the economy and the volume of credit that could be created by banks. These instruments are open market operation, reserve requirement, and discount window operation (i.e. discount rate or monetary policy rate).

The ultimate target of monetary policy is to influence the level of economic activities towards growth of national output, that is, economic growth, which is more of expansion in industrial production capacity of the economy. Industrial growth, therefore, is highly imperative, as a direct consequence of the various roles the industrial sector plays in an economy. This accounts for why Daibi (2014) asserted that, the industry is one of the sectors in the country that contribute to the aggregate economic growth of a nation, and it is regarded as the engine of growth and soul of a nation. This notion was strongly supported by Uzoma, Bowale and Ogundipe (2017), when they expressed that, industries engage in the production of goods for consumption, and as well serve as a tool for accelerating economic growth, and channel through which foreign currency can be earned through either exportation of locally made goods or inward flow of foreign direct investment. It is a catalyst for a sustainable transformation and economic development, as shown in the experiences of some developed and emerging economies such as China, India, Malaysia, North Korea and Singapore. 
The CBN Statistical Bulletin (2016) sub-divided the industrial sector into different sub-sectors, which include Crude Petroleum and Natural Gas, Solid Minerals, and Manufacturing. Therefore, the combined performance of these subsectors would interpret the general performance of the industrial sector. The crude petroleum and natural gas sub-sector contributed the highest percentage, which was $22 \%$ in 2005, to aggregate output, while its contribution in other years, before and after, have been below this figure. It got worse in 2016 by a reduction to $5.29 \%$. The manufacturing sub-sector contributed the highest, which was $28.7 \%$ in 1987,to the aggregate output, while its contributions in the other years after were below this figure; for example, in 2010, it reduced to 6.55\%. The solid mineral sub- sector has been the worst hit with $5.12 \%$ as its highest contribution to the aggregate output in 1986. It fell to $0.09 \%$ in 2010, though appreciated, in 2015 ,to $0.12 \%$ (See CBN Statistical Bulletin, 2016). From all these indications, the contributions and performances of these subsectors have been on the reverse gear, as such, the industrial sector has been a switchback in recent time.

This reported case defies expectation in the face of strong and virile monetary policy measures on the threshold of theoretical postulations, though the theoretical link between monetary policy and industrial growth has been one of the contentious subjects in literature: for, there are, essentially, two schools of thought on this subject. The first line of thought is that which follows Keynes (1936), forming the Keynesian school, while the second thought follows McKinnon(1973) and Shaw (1973), which became McKinnon-Shaw hypothesis, forming the financial liberalization school. To Keynesians, a discretionary change in money supply permanently influences real output by lowering the rate of interest, and through the marginal efficiency of capital, stimulates investment and output growth (Molho, 1986; Athukorala, 1998). The implication of this is that, monetary policy is believed to affect industrial growth. In contrast to this, McKinnon and Shaw advocated the notion of financial liberalization, and argued that, a market force, induced by higher interest rate, would, naturally, enhance more investment by channeling savings to productive investment, thereby stimulating real output growth. The implicit assumption of this, is that, monetary policy does not affect industrial growth.

Consequent upon this, extant literature has not been able to provide a resolved statistical link between monetary policy measures and output growth. Also, previous studies were unable to differentiate between the direct monetary policy instruments and the market-based instruments of monetary policy. Additionally, most of the previous works did not disaggregate economic growth into different sectors, as they examined the impact of monetary policy on the real economic growth. It was against this backdrop that, this study was initiated to investigate the effects of market-based monetary policy instruments on industrial growth in Nigeria, covering a period beginning from 1993 to 2016.

\section{Literature Review}

\subsection{Contextualization}

Monetary policy refers to the combination of measures designed to regulate the value, supply and cost of money in an economy in consonance with the level of economic activities. It can be described as the art of controlling the direction and movement of monetary and credit facilities in pursuance of stable price and economic growth in the economy (CBN 2008). The strong point of this definition is that, it sees monetary policy as a combination of monetary measures and regulatory mechanisms for controlling monetary aggregates/ variables- value, supply and cost of money, for influencing the level of economic activities. Its weak point, however, is that, it sees monetary policy as an art, whereas, it is a 'policy', a rule of guidance, a course of action, and a deliberate and conscious effort geared towards directing and controlling the activities of monetary/ financial institutions.

Further to this, Onipede and Ayodeji (2005) asserted that, monetary policy is the policy adopted when the government wants to influence the level of economic activities through the manipulation of certain monetary measures by controlling the banks and other non-banking financial institutions. The central bank exerts control over all other banking institutions through the following measures and mechanisms: open market operation, bank rate, cash ratio, liquidity ratio, special deposit, moral suasion, directives and funding. A deep analysis of this assertion shows that, monetary policy is an economic policy of the government, this being the central government, through the instrumentality of the central bank (central monetary authority). It also portends that, the ultimate objective of the policy is to influence the level of economic activities such as money supply, employment, price level, foreign exchange, national output (gross domestic product), etc. The tools or instruments of monetary policy are the monetary measures or mechanism used to directly control banks and non-bank financial institutions, which would, in turn, influence the level of economic activities. The implication of this is that, the monetary authority does not have direct control over the level of economic activities but it can influence it by indirect means.

Monetary policy as a course of action taken by public authorities (central banks) to influence the decision of other financial intermediaries in the system (deposit banks, discount companies and other specialized banks, insurance companies, etc.) in pursuance of certain objectives concerning monetary phenomena which relates to the impact of changes in them and economic activities in general (Amoo, Odey, Kanya, Eboreime, Ekeocha, Akpan \& Ochu, 2014). This definition portends the following: First, that monetary policy is a deliberate and conscious action of the central government through the instrumentality of its monetary authority, called central bank. Second, this action is geared towards influencing the level of economic activities in the country. Third, it involves changes in monetary phenomena, such as the use of money and credit, and the volume of money or credit. Fourth, these changes influence the decisions of other financial institutions, such as deposit money banks, insurance companies, discount houses and primary and secondary mortgage institutions. Fifth, monetary policy is purposeful, having certain objectives, which are stabilization, growth and sustainable development. Hence, monetary policy is a deliberate effort by the monetary authority to control the supply of money and credit conditions in order to achieve certain broad economic objectives (Uzoma et al, 2017). 
Monetary policy objective may be expansionary or contractionary depending on the profile or state of the economy and the interest of the monetary authority. An expansionary monetary policy objective seeks to increase the total money supply in the economy with the prime intention of reducing the rate of unemployment and stimulating economic growth. Contractionary monetary policy, on the other hand, seeks to reduce the volume of money in the economy, by mopping up excess liquidity therefrom, with the intention of combating inflation and its attendant effects.Accounting for these, the CBN Monetary Policy Framework (2011) states that, expansionary policy is, traditionally, an attempt to combat unemployment in a recession by lowering interest rates in the hope that easy credit will ease businesses into expanding. Contractionary policy is intended to slow inflation in order to avoid the resulting distortion and deterioration of assets in the economy. The Framework further classified monetary policy objectives into three: operating targets, intermediate targets and ultimate targets.

Operating target is the monetary policy objective, which seeks to achieve short-term economic stability (usually within six months) through short-term interest rate and reserve money (i.e. monetary base and non-borrowed reserve). Intermediate targets are the monetary policy objectives, which seeks to influence macroeconomic variables indirectly through monetary aggregate (narrow money, $\mathrm{M}_{1}$; broad money, $\mathrm{M}_{2}$ ), short and long term interest rates, and aggregate demand. Fundamentally, these macroeconomic variables are not under the control of the central monetary authority, but they can be influenced indirectly by it. The ultimate target is a monetary policy objective, which seeks to achieve major macroeconomic objectives such as low unemployment rate, low inflation rate, favourable exchange rate, financial market stability, balance of payment equilibrium (or external balance), and growth in gross domestic product.

Out of these three classifications of monetary policy objectives, the ultimate target is more pronounced in literature. For example, Adigwe, Echekoba and Onyeaoba (2015) asserted that, monetary policy objectives includes price stability, maintenance of balance of payments equilibrium, promotion of employment and output growth and sustainable development. Similarly, Okonkwo, Egbulonu and Mmaduabuchi(2015) opined that, monetary policy, in Nigeria, is to ensure price and monetary stability. For the achievement of these objectives, instrumental variables (i.e. monetary policy instruments) are deployed. These are classified into direct instruments and indirect instruments; the latter being marketbased monetary policy instruments (CBN Monetary Policy Framework, 2011).

Market-based monetary policy instruments are referred to as short-term stabilization tools by Olofin and Salisu (2001), stating that, assuming short-term stabilization were the concern of the central bank, these tools fall into three major categories, which are: conduct of open market operations, changes in the discount rate (referred to in Nigeria as monetary policy rate, MPR), and changes in the reserve ratio. Any of these three measures, or a combination of them, can be aimed at regulating the level of money supply and, by so doing, the general level of economic activity. However, Ishola (2011) referred to these market-based instruments as quantitative controls, stating that, traditionally, there are three tools under this category; namely, the open market operations, the legal reserve ratio and the bank rate. They are quantitative controls because their main aim is to regulate the quantity of money in circulation and the volume of credit that would be created by the commercial banking system, since these credits constitute part of the money supply.

Open market operation is an instrument of monetary policy, which involves the buying and selling of government securities in the open market, through the deposit money banks in order to control the volume of money supply for stabilizing the economy, depending on the profile of the economy. These government securities are treasury bills, treasury certificates and government bonds. If the profile of the economy is such that, the volume of money in circulation is too high with inflationary pressures, the central bank would sell government securities to the public, through the deposit money banks from their deposit accounts, thus the reserves of these banks are reduced, the quantity of money with the deposit money banks is reduced, and their ability to grant loans and advances to the public is reduced (Onipede \& Ayodeji, 2005). When money supply falls, the rate of interest rises and the consequential effect of this is that, the level of effect and economic activities will fall. This is a contractionary monetary policy, as it tightens the economy (Olofin \& Salisu, 2001). But when the central bank buys back government securities from the public and pays them through the deposit money banks, the reserves of these banks are increased, the volume of money in possession of deposit money banks is increased, as it drains cash from the central bank, and the lending ability of the deposit money banks to the public is increased, thus the volume of money in circulation is increased: It is an expansionary monetary policy (Solomon \& Olaleye, 2001; Ishola, 2011).

The legal reserve requirement is a legal instrument of monetary policy. By this instrument, deposit money banks are required to keep a certain percentage or proportion of their total deposits with the central bank in cash; hence, it is called cash reserve ratio or legal reserve ratio (Solomon \& Olaleye, 2001). It is measured by cash reserve ratio and/ or liquidity ratio (Ishola, 2011). Given this reserve requirement, the capacity of deposit money banks to grant loans by multiple-credit expansion is restricted (Olofin \& Salisu, 2001). If the central bank intends to embark on a contractionary monetary policy, it raises the cash reserve ratio, which will, in turn, reduce the quantity of money at the disposal of deposit money banks to lend out in the credit expansion process; hence, their lending ability is reduced; and as such, the volume of money supply is reduced. Conversely, if the central bank wishes to embark on expansionary monetary policy, it lowers the cash reserve ratio, so that the deposit money banks can have more money to lend out and increase the level of economic activities (Onipede \& Ayodeji, 2005).

Discount rate, or monetary policy rate,is the rate at which the central bank rediscounts bills and gives loans to deposit money banks as their lender of last resort (Ishola, 2011). This rate is usually specified in the annual monetary policy guidelines or circular issued by the Central Bank of Nigeria; hence, it is called Monetary Policy Rate (MPR) in Nigeria. However, deposit money banks take out loans from the central bank by way of violating the reserve requirement, or the need to issue credit (Olofin \& Salisu, 2001). This MPR is the prime lending rate, the base rate or the minimum rediscount rate; hence, the lending rate charged by deposit money banks and other financial institutions takes after this 
rate (Ishola, 2011). This is due to the fact that, deposit money banks and other lending institutions would have to add their margin to this rate to get their own lending rate for profitability. However, if the central bank intends to embark on contractionary monetary policy, it will raise the bank rate; by this, the banks' lending rate will increase, and this will discourage borrowing in the economy, thus the level of economic activities will be hampered. But, if the central bank lowers the bank rate, it is embarking on an expansionary monetary policy, and as such, borrowing will be encouraged in the economy, which will, in turn, stimulate investment and the level of activities in the economy (Solomon \& Olaleye, 2001).

A key element of the ultimate targets of monetary policy, which the market-based instruments seek to achieve, is economic growth, that is, growth in Gross Domestic Product, GDP for short (Olofin \& Salisu, 2001; Onipede \& Ayodeji, 2005; CBN Monetary Framework, 2011; Ishola, 2011; Okonkwo et al, 2015). However, the CBN Statistical Bulletin (2016) classifies the components of GDP into five activity sectors; these are: agriculture, industry, construction, trade, and services. Therefore, GDP growth would result from growth in these activity sectors, so that GDP growth can be defined as the combined growth in the contributions of activity sectors to GDP. In simple term, GDP growth is the addition of agricultural output growth, industrial output growth, construction activity growth, trade activity growth and services activity growth.

Accordingly, agricultural output growth is the continuous increase in the contributions of agriculture sector to the growth in GDP; industrial output growth (industrial growth for short) is the continuous increase in the contributions of industrial sector to the growth in GDP; construction activity growth is the continuous increase in the contributions of construction sector to the growth in GDP; trade activity growth is the continuous increase in the contributions of trade sector to the growth in GDP; and services activity growth is the continuous increase in the contributions of service sector to the growth in GDP. Howbeit, contextualizing industrial growth is our concern. An industry is the coming together of firms or group of firms producing either identical or similar products (Balami, 2006). Hence, industrial growth is the continuous increase in the total output from industrial sector of an economy. This increase in industrial production must be consistently experienced so that it can have a positive effect on GDP growth, and translate to economic growth.

\subsection{Theoretical Framework}

The basic theoretical framework for analyzing monetary policy is the traditional Keynesian IS-LM framework. The mechanism is such that, changes in monetary policy, usually specified as exogenous shifts in monetary aggregates, affect the money supply, which changes interest rate to balance demand with supply. The changes in interest rates, then, affect investment and consumption, which latter cause changes in output and, eventually, prices. This theory is applicable to influencing the level of economic activities through appropriate changes in monetary aggregates, thus embarking on either expansionary or contractionary monetary policy.

The IS-LM model was developed by J. R. Hicks in 1937, and was later advanced by A. H. Hansen in1953. The main thrust behind the development of this theoretical model is to provide an interpretation of Keynes' General Theory of Employment, Interest and Money (Ayodele, 1988). The theory focused on the equilibrium position between the demand and the supply of money to determine the rate of interest, which influences investment spending and, consequently, output level (Dornbusch, Fischer \& Richard, 2002). The IS-LM model is the conceptual structure for the inter-relationship between the real sector (goods market or real market) and the financial sector (money market) in an economy. The goods market is represented by the IS curve while the money market is represented by the LM curve, so that the interactions between the two markets can be explained by the IS-LM model.

The goods market is concerned with the determination of equilibrium level of output (national product) with its attendant variables for attaining it, which are the level of household consumption and the level of savings or investment (since savings equals investment in national income determination) for attaining equilibrium output (Ayodele, 1988). As such, the goods market is concerned with the determination of equilibrium level of output (Y) with the level of savings (S) and investment (I) for attaining it (Olofin \& Salisu, 2014); so that, the IS curve depicts the equality of savings and investment at various combinations of the levels of income and rates of interest in the real market (Ishola, 2011; Jhingan, 2011). The money market, on the other hand, is concerned with the determination of equilibrium rate of interest with the attendant variables for attaining it, which are demand for and supply of money (Ayodele, 1988; Ishola, 2011); so that, the LM curve depicts the equality of demand for and supply of money at various combinations of levels of income and rates of interest in the money market (Ishola, 2011; Jhingan, 2011).

Thus, the nexus between the goods market (IS curve) and the money market (LM curve) is influenced by the rate of interest, so that, any shock or variability occasioned by rate of interest in one market will affect the other market. However, Ayodele (1988) noted that, the effects of these changes would initiate interactive process between the two markets until equilibrium is reached. The aim of the IS-LM model is to provide a comparative static framework in which the new equilibrium for the economy can be established when both the real and money markets are in equilibrium. This can be established by finding the rate of interest, which would enable both markets to be at equilibrium with the same level of income. When interest rate in the real market is higher than in the money market, investors or businessmen will borrow from the money market because of the low interest and invest, in capital market, thereby increasing the level of income via investment multiplier. On the other hand, when the interest rate in the money market is higher, investors will sell or discharge debt in the money market rather than invest in capital market. This will bring down the investment, and reduce the income by multiplier (Jhingan, 2011). 


\subsection{Empirical Review}

Lawson and Rees (2008) examined the effects of unanticipated changes in monetary policy on expenditure and production components of Gross Domestic Product (GDP) in the Australian economy from 1983 to 2007. Employing structural vector autoregressive model, the study found heterogeneous response of the components of GDP to monetary policy impulses, such that dwelling investment, as well as machinery and equipment investment, were the most interestsensitive expenditure components of GDP, while construction and retail trade sectors were the most interest-sensitive production components of GDP. However, Mehdi and Motiee (2011) estimated the major determinants of monetary policy and their effects on industrial sector growth in Iran, within the period of 1961-2007. The study employed interest rate, exchange rate, private sector credit, all share price index and consumer price index as proxies for monetary policy. Using auto-regressive distributed lag model, as the estimation technique, it found that, monetary policy effects are felt, by the industrial sector, mostly through exchange rate and bank credit channels.

Okulegu, Onwe and Okoro (2013) estimated the long-runeffects of monetary policy instruments on economic growth in Nigeria,within the time frame of 1980-2009. Sourcing data from CBN Statistical Bulletins, monetary policy was proxied by money supply, interest rate, exchange rate and credit to the economy, while GDP was used to proxy economic growth. The study adopted co-integration, error correction model and Granger causality test as estimation techniques, and found that, monetary policy instruments significantly influence the rate of growth of the Nigerian economy, and that a long-run relationship exists between the two variables.Similarly, Sulaiman and Migiro (2014) assessed the relationship between monetary policy and economic growth in Nigeria from 1981 to 2012. The study sourced secondary data from CBN Statistical Bulletins, and proxied monetary policy by cash reserve ratio, monetary policy rate, exchange rate, money supply and interest rate; economic growth was proxied by gross domestic product. Using the Johansen co-integration test and Granger causality test, it found a long-run relationship between monetary policy and economic growth in Nigeria, and a unidirectional causality between them, running from monetary policy to economic growth.

Nevertheless, Owolabi and Adegbite (2014) examined the effects of monetary policy on industrial growth in Nigeria, spanning over a period from 1970 to 2010. The study employed treasury bills, deposit, and rediscount rate as monetary policy variables, and manufacturing outputas the proxy for industrial growth. Sourcing secondary data from the CBN Statistical Bulletins, and employing multiple regression analysis to estimate them, it found that, all the proxies of monetary policy have significant relationship with industrial growth, such that rediscount rate, and deposit have significant positive effect on industrial output while treasury bills have negative impact on industrial output. But, Adigwe et al (2015) investigated the impact of monetary policy on the Nigerian economy between 1980 and 2010. The study employed liquidity ratio, money supply, cash reserve ratio, interest rate and exchange rate as monetary variables; also, it used gross domestic product and inflation rate as two proxies for economic growth, thus forming two models. Obtaining secondary data from CBN Statistical Bulletins, and analyzing them with ordinary least square method, it found liquidity ratio and cash reserve to have positive and insignificant effect while money supply have significant positive effect on economic growth in Nigeria. It also found that both interest rate and exchange rate have negative effects on inflation rate in Nigeria.

Okonkwo et al (2015) examined the effects of monetary policy variables on manufacturing sub- sector in Nigeria from 1981 to 2012. Secondary data were sourced from CBN Statistical Bulletins, National Bureau of Statistics and CBN Annual Reports, and were estimated using Johansen co- integration test, error correction model and ordinary least square method. The study found that, out of money supply, inflation and credit to the private sector, which were used to proxy monetary policy, money supply and credit to private sector are more significant in influencing manufacturing sub-sector in Nigeria. Similarly, Nwoko, Ihemeje and Anumadu (2016) considered the effects of monetary policy on economic growth in Nigeria between 1990 and 2011. Gross domestic product was used to proxy economic growth, while money supply, average price, interest rate and labour force were employed as proxies for monetary policy. The study sourced data from CBN Statistical Bulletins and estimated them using multiple regression analysis. It found that, average price and labour force had significant influence on gross domestic product while the influence of money supply was not significant; butthe influence of interest rate was negative and statistically significant.

\section{Methodology}

The study employed ex-post-facto(i.e. after-the-fact) research design. Relevant data were sourced from CBN Statistical Bulletins and CBN Annual Abstract of Statistics from 1993 to 2016. The conventional method of using proxies was adopted, such that, the proxy for the dependent variable (Industrial Growth) was industrial sector contribution to GDP (INDGR), while the proxies of the independent variable (market-based monetary policy instruments) are monetary policy rate (MPR), open market operation (OMO), and Liquid Ratio (LR). Estimation techniques used were Augmented Dickey Fuller test, auto regressive distributed lag model and vector auto regression.

\subsection{Model Specification}

The model for this study was based on the statistical model of multiple regression approach in line with that which was applied by Adigwe et al (2015). This model adapted is stated below:

$$
\mathrm{RGDP}_{\mathrm{t}}=\beta_{0}+\mathrm{LR}_{\mathrm{t}}+\mathrm{RSR}_{\mathrm{t}}+\mathrm{MS}_{\mathrm{t}}+\mu_{\mathrm{t}}
$$

$$
\text { ............1 }
$$

That is, economic growth is dependent on liquid ratio, reserve requirement, and money supply.

However, this model was adapted, by this study, to include open market operation and monetary policy rate, but excluded money supply, in order to capture the actual market-based monetary policy instruments. The new model for the study is, therefore, stated in functional form below:

INDGR $=f(M P R, O M O, L R)$ -...........2 
The model is restated in an explicit form thus:
$\mathrm{INDGR}_{\mathrm{t}}=$
$\alpha 0+\alpha_{1} \mathrm{MPR}_{\mathrm{t}}+\alpha_{2} \mathrm{OMO}_{\mathrm{t}}+\alpha_{3} \mathrm{LRR}_{\mathrm{t}}+\mu_{\mathrm{t}}$
.............3

In order to bring all the variables into the same parenthesis, logarithm was introduced, and the new model was re-stated thus:

LINDGR $_{t} \quad=\quad \alpha 0+\alpha_{1} M_{P R}+\alpha_{2} L_{O M M O}+\alpha_{3} L_{R R}+\mu_{t}$

The modified model for industrial growth using vector auto regression model is stated below:

INDGR $_{\mathrm{t}}=\lambda_{1}+\alpha_{11} \sum$ Indgr $_{\mathrm{t}-1}+\alpha_{12} \sum \mathrm{Mpr}_{\mathrm{t}-1}+\alpha_{13} \sum 0 \mathrm{mo} \mathrm{t}-1+\alpha_{14} \sum \operatorname{Lrr}_{\mathrm{t}-1}+\varepsilon_{1}$

$\mathrm{MPR}_{\mathrm{t}} \quad=\lambda_{2}+\alpha_{21} \sum$ Indgr $_{\mathrm{t}-1}+\alpha_{22} \sum \mathrm{Mpr}_{\mathrm{t}-1}+\alpha_{23} \sum \mathrm{Omo} \mathrm{t}-1_{\mathrm{t}}+\alpha_{24} \sum \mathrm{Lrrr}_{\mathrm{t}-1}+\varepsilon_{1} \quad \ldots \ldots \ldots \ldots .6$

$\mathrm{OMO}_{\mathrm{t}} \quad=\lambda_{3}+\alpha_{31} \sum$ Indgr $_{\mathrm{t}-1}+\alpha_{32} \sum \mathrm{Mpr}_{\mathrm{t}-1}+\alpha_{33} \sum \mathrm{Omo}_{\mathrm{t}-1}+\alpha_{34} \sum \mathrm{Lrr}_{\mathrm{t}-1}+\varepsilon_{1} \quad \ldots \ldots \ldots \ldots . . .7$

$\mathrm{LR}_{\mathrm{t}} \quad=\lambda_{4}+\alpha_{41} \sum$ Indgr $_{\mathrm{t}-1}+\alpha_{42} \sum \mathrm{Mpr}_{\mathrm{t}-1}+\alpha_{43} \sum \mathrm{Omo}_{\mathrm{t}-1}+\alpha_{44} \sum \mathrm{Lrr}_{\mathrm{t}-1}+\varepsilon_{1} \quad \ldots \ldots \ldots \ldots . . .8$

Where:

$\mathrm{L}=$ Logarithm; $\mathrm{INDG}_{\mathrm{t}}=$ Industry output; $\mathrm{MPR}=$ Monetary Policy Rate; $\mathrm{OMO}=$ Open Market Operation; LRR =Legal Reserve Requirement (proxied by liquidity ratio); $\mu_{\mathrm{t}}=$ Error term; $\alpha_{1}, \alpha_{2} \alpha_{3}=$ Parameters or coefficients of MPR, OMO and LR respectively.

\section{Results and Findings}

\subsection{Augmented Dickey Fuller (ADF) Unit Root Result}

The standard Augmented Dickey-Fuller (ADF) unit root test was used to check the order of integration of the variables; the results obtained are reported in Table 1 below. Based on the result of ADF test statistic, it was observed that all the variables in the study became stationary at first difference l(1) except for MPR that became stationary at level $1(0)$. This indicates that, the variables in the model are integrated at different orders. The null hypothesis of the ADF test is that, the series is non-stationary, containing a unit root; this was rejected, and so, the alternate hypothesis was accepted, as it states that, the series is stationary, having no unit root. The rejection of the null hypothesis is based on McKinnon (1996) critical values. The lag length are selected based on Schwartz Information Criterion (SIC), this ranges from lag zero to lag two.

\begin{tabular}{|c|c|c|c|c|c|}
\hline Variable & ADF Statistic & Critical value & DW & Lag & Inference \\
\hline INDGR & -3.1258 & -3.0048 & 1.99 & 2 & $\mathrm{I}(1)$ \\
\hline MPR & -4.2116 & -2.9980 & 1.5663 & 2 & $\mathrm{I}(0)$ \\
\hline OMO & -5.5611 & -3.0048 & 1.6363 & 2 & $\mathrm{I}(1)$ \\
\hline LRR & -5.3811 & -3.0048 & 1.8349 & 2 & $\mathrm{I}(1)$ \\
\hline
\end{tabular}

Table 1: Results of Augmented Dickey Fuller (ADF) Stationary Test

Source: Author's Computation, 2018

\subsection{Test of Heteroskedasticity}

To test for the normality of the series, Breusch Pagan Godfrey test was adopted, and the results are displayed in Table 2 below. It was obtained that, the series is normally distributed, as the F-statistic result of 1.024 is significant, having a p-value of 0.4563 at $5 \%$ level of significance. Therefore, the study concluded that, the series is normally distributed and free from heteroskedasticity, that is, the series has no constant variance

\begin{tabular}{|c|c|c|c|}
\hline \multicolumn{4}{|c|}{ Heteroskedasticity Test: Breusch-Pagan-Godfrey } \\
\hline F-statistic & 1.024457 & Prob. F(7,14) & 0.4563 \\
\hline Obs*R-squared & 7.451934 & Prob. Chi-Square(7) & 0.3834 \\
\hline Scaled explained SS & 2.061589 & Prob. Chi-Square(7) & 0.9564 \\
\hline
\end{tabular}

Table 2: Summary of Breusch Pagan Godfrey Test

Source: Author's Computation, 2018

\subsection{Auto-Regressive Distributed Lag (ARDL) Bound Testing}

The ARDL bound testing was employed to test for the existence of long-run relationship between the variables in the model. With ADF test results obtained above, the ARDL bound testing was suitable for this study. Accordingly, the Fstatistic result obtained was compared with the critical bound value at $5 \%$ level of significance; and it was revealed that, the F-statistic (5.067) is greater than the critical bound values, at the lower level of 3.23 and the upper level of 4.35, at 5\% level of significance. As a direct consequence of this, the study concluded that, there exists a long-run relationship between market-based monetary policy instruments and industrial growth in Nigeria; as such, these variables moved jointly in the long-run. 


\begin{tabular}{|c|c|c|}
\hline Test Statistic & Value & K \\
\hline F-statistic & 5.067186 & 3 \\
\hline \multicolumn{3}{|c|}{ Critical Value Bounds } \\
\hline Significance & I0 Bound & I1 Bound \\
\hline $10 \%$ & 2.72 & 3.77 \\
\hline $5 \%$ & 3.23 & 4.35 \\
\hline $2.50 \%$ & 3.69 & 4.89 \\
\hline $1 \%$ & 4.29 & 5.61 \\
\hline
\end{tabular}

Table 3: Summary of ARDL Bound Testing

Source: Author's Computation, 2018

\subsection{VAR Lag Order Selection}

Considering the limited length of the data series, maximum length lag of 1 was permitted in the selection of the optimum lag length to be used in the estimation of the VAR model as shown on Table 4 below. The Akaike Information Criterion (AIC), Hannan-Quinn Information Criterion (HQ) and the Schwartz Information Criterion (SIC) were employed for the VAR lag order selection. The optimum lag order of one suggested that, the selection criteria satisfy the stability condition.

\begin{tabular}{|c|c|c|c|c|c|c|}
\hline & & VAR & Order Sele & n Criteria & & \\
\hline & & Endogenou & ariables: IN & R OMO MPR & & \\
\hline & & & genous val & les: $\mathrm{C}$ & & \\
\hline & & & )8/23/18 & e: 13:04 & & \\
\hline & & & ample: 199 & & & \\
\hline & & & ded observ & ns: 22 & & \\
\hline Lag & LogL & LRR & FPE & AIC & SC & HQ \\
\hline 0 & -505.6460 & NA & $1.55 \mathrm{e}+15$ & 46.33145 & 46.52983 & 46.37818 \\
\hline 1 & -459.0812 & 71.96370* & $9.97 \mathrm{e}+13^{*}$ & 43.55284 & $44.54470^{*}$ & 43.78649* \\
\hline 2 & -442.8127 & 19.22647 & $1.16 e+14$ & 43.52843* & 45.31377 & 43.94900 \\
\hline
\end{tabular}

Table 4: Summary of Lag Length Selection

Source: Author's Computation, 2018

\subsection{Impulse Response of the Series to the Exogenous Variable}

Impulse Response Function results describe the responsiveness of innovations to Cholesky one standard deviation or exogenous shocks over time. Therefore, to check for the response of industrial growth to shocks or innovation from market-based monetary policy instruments, the impulse response of VAR was used. Thus, the impulse response results show how industrial growth reacted to each of the market-based monetary policy instruments within the first 10 years.

Results from Table 5 below show that, in the first year, industrial growth responded to its own innovation, as it records 1050.358 while there was no shocks from the market-based monetary policy instruments, having 0.00000 each. In the second year, industrial growth reacted to impulses from all the market-based monetary policy instruments, including own innovation (which reduced from 1050.358 to 1046.395). However, open market operation and monetary policy rate sent negative impulses to industrial growth, recording -176.2153 and -683.2109 respectively, while legal reserve ratio conveyed positive impulses to industrial growth, recording 176.2987. In the third year, own shocks reduced to 1012.78; however, shocks from open market operation were positive on industrial growth, recording 342.2009, while impulses from monetary policy rate and legal reserve requirement were negative, recording -1303.047 and -104.1715 respectively.

The results of the fourth year are similar to those of the third year in terms of direction of impulses, whether positive or negative. This trend continued from Year 5 to Year 10, as open market operation and monetary policy rate continued to transmit negative impulses, and legal reserve requirement transmitted positive impulses to industrial growth throughout this period. Worthy of note are the facts that, industrial growth's responses to its own innovations were positive throughout, and such responses (or reactions) were constantly reducing from year to year throughout the period under consideration. The adducible reason to this fact is that, the combined shocks or impulses from the market-based monetary policy instruments on industrial growth has been effectual. The implication of this is that, industrial growth responded significantly to monetary policy shocks in Nigeria within the year of review. The direction of these shocks had been positive from own innovations and legal reserve requirement but negative from open market operation and monetary policy rate, as depicted by Table 5 and Figure 1 below 


\begin{tabular}{|c|c|c|c|c|}
\hline \multicolumn{5}{|c|}{ Response of INDGR } \\
\hline Period & INDGR & OMO & MPR & LRR \\
\hline 1 & 1050.358 & 0.000000 & 0.000000 & 0.000000 \\
\hline & $(158.347)$ & $(0.00000)$ & $(0.00000)$ & $(0.00000)$ \\
\hline 2 & 1046.395 & -176.2153 & -683.2109 & 176.2987 \\
\hline & $(293.997)$ & $(320.735)$ & $(273.499)$ & $(261.287)$ \\
\hline & 1012.778 & 342.2009 & -1303.047 & -104.1715 \\
\hline 4 & $(418.248)$ & $(520.516)$ & $(443.404)$ & $(390.255)$ \\
\hline & 674.7567 & 27.70327 & -1987.326 & -65.43974 \\
\hline 5 & $(569.936)$ & $(712.587)$ & $(656.635)$ & $(561.390)$ \\
\hline & 539.6145 & -39.61542 & -2206.562 & 106.1992 \\
\hline 6 & $(665.944)$ & $(874.683)$ & $(853.369)$ & $(733.394)$ \\
\hline & 428.0915 & -269.9207 & -2155.725 & 363.5896 \\
\hline & $(702.849)$ & $(969.056)$ & $(1012.34)$ & $(863.151)$ \\
\hline \hline & 410.1351 & -256.7776 & -1942.845 & 532.3786 \\
\hline & $(692.909)$ & $(989.415)$ & $(1118.52)$ & $(938.405)$ \\
\hline & 343.4051 & -274.6909 & -1731.463 & 584.7647 \\
\hline & $(655.142)$ & $(955.648)$ & $(1163.25)$ & $(939.867)$ \\
\hline & 265.5844 & -217.3039 & -1542.789 & 557.4871 \\
\hline & $(620.781)$ & $(887.996)$ & $(1164.81)$ & $(901.782)$ \\
\hline & 157.8820 & -216.2894 & -1357.426 & 501.5000 \\
\hline & $(589.482)$ & $(808.564)$ & $(1148.26)$ & $(845.570)$ \\
\hline
\end{tabular}

Table 5: Summary of Impulse Response Function Results Source: Author's Computation, 2018
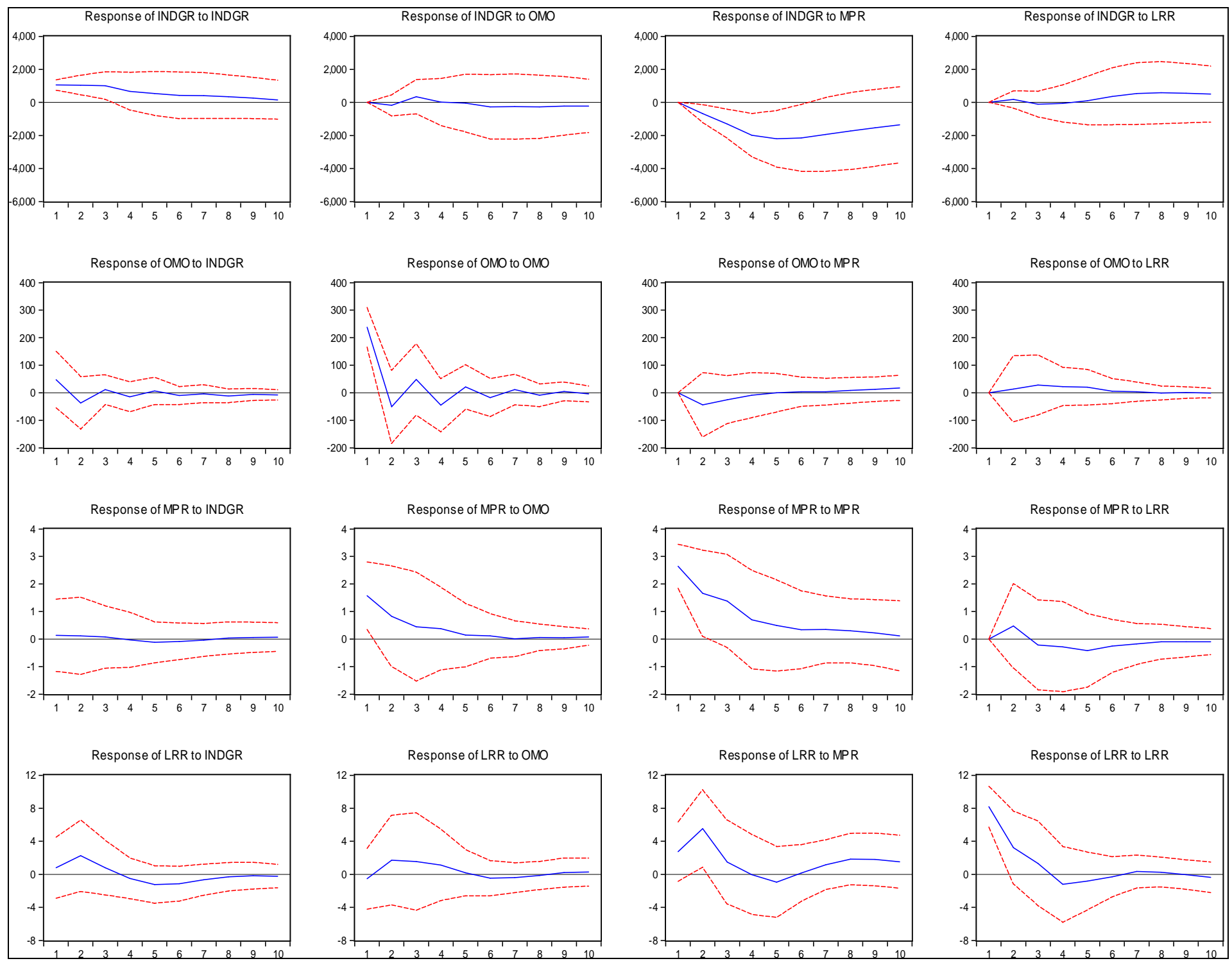

Figure 1: Graphical Representation of Impulse Response Function Results 


\subsection{Variance Decomposition Error}

In order to identify or establish the market-based instrument of monetary policy that explains more of the variability in industrial growth (INDGR), the study employed variance decomposition error. The first 10 years forecast was employed, as this range is considerable enough for establishing a consistent pattern upon which generalization can be made about future years with respect to the variables of interest. The results of variance decomposition error are contained in Table 6 below.

From Table 6, it can be obtained that, in the first year, variations in industrial growth were explained by its own innovation, recording $100 \%$, and no shock was recorded from any of the market-based monetary policy instruments. In the second year, variations of 80.60 in industrial growth were explained by shocks from market-based monetary policy instruments, with monetary policy rate recording the highest(17.11) while open market operation and legal reserve requirement recorded 1.138637 and 1.139714 respectively.

In the fourth year, variations in industrial growth were 36.83 with shocks from monetary policy rate recordingthe highest,again, at 61.21; open market operation recorded 1.49 and legal reserve requirement recorded 0.46 . From the fifth to the tenth year, monetary policy rate continued to account for the largest variations in industrial growth. Also, in the fifth and sixth year, open market operation recorded 0.992583 and 1.105848 respectively, while legal reserve requirement recorded 0.379208 and 0.93907 respectively; so, to this extent, from Year 1 to Year 6, open market operation ranked next to monetary policy rate; however, from Year 7 to Year 10, the turn of events changed between open market operation and legal reserve requirement, so that legal reserve requirement ranked next to monetary policy rate within this period. In other words, monetary policy rate accounted for the largest variation in industrial growth while open market operation accounted for the second largest variation within the first six years, and legal reserve requirement accounted for the second largest variation from the seventh year to the tenth year.

\begin{tabular}{|c|c|c|c|c|c|}
\hline \multicolumn{7}{|c|}{ Variance Decomposition of INDGR } \\
\hline Period & S.E. & INDGR & OMO & MPR & LRR \\
\hline 1 & 1050.358 & 100.0000 & 0.000000 & 0.000000 & 0.000000 \\
\hline 2 & 1651.395 & 80.60544 & 1.138637 & 17.11621 & 1.139714 \\
\hline 3 & 2361.929 & 57.78963 & 2.655691 & 38.80302 & 0.751660 \\
\hline 4 & 3160.462 & 36.83441 & 1.490919 & 61.21199 & 0.462684 \\
\hline 5 & 3893.773 & 26.18741 & 0.992583 & 72.44080 & 0.379208 \\
\hline 6 & 4494.100 & 20.56579 & 1.105848 & 77.38916 & 0.939207 \\
\hline 7 & 4948.652 & 17.64810 & 1.181266 & 79.23869 & 1.931949 \\
\hline 8 & 5293.624 & 15.84371 & 1.301589 & 79.94607 & 2.908624 \\
\hline 9 & 5552.585 & 14.62912 & 1.336173 & 80.38302 & 3.651690 \\
\hline 10 & 5744.302 & 13.74445 & 1.390245 & 80.69110 & 4.174202 \\
\hline
\end{tabular}

Table 6: Summary of Variance Decomposition Error Results

Source: Author's Computation, 2018

\section{Discussion of Findings}

This study considered the sensitivity or responsiveness of industrial growth, in Nigeria, to the three market-based monetary policy instruments, that is, monetary policy rate, open market operation and legal reserve requirement. On that account, this study found the following: First, there is a long-run relationship between market-based monetary policy instruments and industrial growth in Nigeria. Second, industrial growth significantly responded to own innovations and impulses from all the three market-based monetary policy instruments. Third, industrial growth responded positively to own innovations and legal reserve requirement, but negatively to open market operation and monetary policy rate. Fourth, monetary policy rate accounted for the largest variation in industrial growth; however, for the second largest variation, it was initially accounted for by open market operation, but was finally accounted for by legal reserve requirement. Thus, the findings of this study are in support of the traditional Keynesian IS-LM framework, which state that, charges in monetary aggregate (i.e. monetary policy variables) would affect the real sector.

Not only that, the findings of this study are conformable with those of Okulegu et al (2013), Sulaiman and Migiro (2014), and Okonkwo et al (2015), who found that, a long-run relationship exists between monetary policy variables and either industrial growth or economic growth in Nigeria. Also, results emanating from this study are in agreement with those of Lawson and Rees(2008), Owolabi and Adegbite (2014), Adigwe et al (2015), and Nwoko et al (2016), who found that monetary policy variables had significant effect on industrial and economic growth in Nigeria. Though, these researchers employed less-rigorous estimation techniques (ordinary least squares or multiple regression analysis), the findings of this study tow the same line with theirs. Therefore, the findings of this study reflect the contributions of the market-based monetary policy instruments to industrial growth in Nigeria.

\section{Conclusion and Recommendation}

The study examined the effects of market-based monetary policy instruments on industrial growth in Nigeria, within a time frame of 1993 - 2016. Upon the threshold of the traditional Keynesian IS-LM model, and findings emanating from the employment of auto-regressive distributed lag model and vector auto-regression impulse response function, the study concluded that, market-based monetary policy instruments have significant effects on industrial growth in Nigeria, such that positive impulses are conveyed by legal reserve requirements, and negative impulses are transmitted by 
monetary policy rate and open market operations, to industrial growth in Nigeria.It was therefore, recommended that, the central government should follow monetary policy initiatives that would stimulate industrial growth in Nigeria, as this has a greater tendency to engender economic growth and development in the country. More importantly, as much as government would want to stabilize the general price level, (i.e. regulating the quantity of money in circulation), the longterm effect of variations in monetary policy rate, open market operation and legal reserve requirement on industrial growth should be considered, as industrial growth responds significantly to impulses or shocks from these monetary policy instruments.

\section{References}

i. Adigwe, P. K., Echekoba, F.N., \& Onyeabo, B.C. (2015). Monetary policy and economy growth in Nigeria: Critical evaluation. Journal of Business and Management, 17(2), 110-119

ii. Amoo, B.A., Odey, L.I., Kanya, W., Eboreime, M., Ekeocha, P., Akpan, N.I., \& Ochu, E.R. (2014). Effect of monetary policy in the real economy of Nigeria; A disaggregated analysis. Central Bank of Nigeria (CBN) Occasion Paper, 54, 1-73.

iii. Athukorala, P. C. (1998). Interest rate, Savings and investments: Evidence from India. Oxford Development Studies, 26(2), 153-169.

iv. Ayodele, S. (1988). Lecture guide on macroeconomics. Zaria: The Nigerian Economics Students Association, Ahmadu Bello University, Zaria Chapter.

v. Balami, D.H. (2006). Macroeconomic theory and practice, fifth edition. Maiduguri: Salawe Prints, Off Leventies, Wulari

vi. Central Bank of Nigeria(2008).CBN Monetary Policy Department Series 1 CBN/ MPD/ Series/ 01/ 2008. http:/ / www.cbn.gov.ng

vii. Central Bank of Nigeria (2011). Understanding monetary policy series 3.Central Bank of Nigeria Monetary Policy Framework, 2-33.http:/ / www.cbn.gov.ng

viii. Central Bank of Nigeria (2016). Statistical Bulletin and Annual Report and Statement of Accounts .Central Bank of Nigeria

ix. Daibi, W.D. (2014). Nigerian industrial development (1943 to 2013): Challenges and International Review of Research in Emerging Market and Global Economy, 1(3), 132-149

x. Dumbusch, R, Fisher, S., \& Richard, S. (2002). Macroeconomics, eight edition. Tata: McGraw-Hill Companies Inc.

xi. Ishola, K. A. (2011). Macroeconomics, Ilorin: Lavgark Investment Limited.

xii. Jhingan, M. L. (2011). Money,Banking, international trade and public finance(8th ed): Vrinda Publications, Delhi.

xiii. Keynes, J. M. (1936). The general theory of employment, interest and money. London: Macmillan Publishers Limited

xiv. Lawson, J. \& Rees, D. (2008). A sectoral model of the Australian economy. Reserve Bank of Australia, Research Discussion Paper 2008-01

xv. Mehdi, S. \& Motiee, R. (2011). A study examining the effect of export growth in Iran. International Business and Management, 3(1), 92-98

xvi. McKinnon, R.I. (1973), Money and capital in economic development. Washington D.C, The Brookings Institute

xvii. Molho, L. E. (1986). Interest rate, savings and investment in developing countries. International Monetary Fund (IMF) Staff Paper, 83 (1), 90-116

xviii. Nwoko,N.N., Ihemeje, J.C.,\&Anumadu, E. (2016). The impact of monetary policy on the Nigeria. African Research Review, International Multidisciplinary Journal, Ethiopia, 10(3), 192-206

xix. Okonkwo, O.N, Egbulonu, K.G.,\& Mmaduabuchi, E.F. (2015). Monetary policy and manufacturing sector in Nigeria. International Journal of Economics and Management $\quad$ Studies, 2(1), 17-25

xx. Okulegu, B. E., Onwe, G. O., \& Okoro, F. T. (2013). Monetary policy instruments and economic growth in Nigeria. International Journal of Social Sciences and Humanities Review, 4 (3), 1-15

xxi. Olofin, S. O., \& Salisu, A. A. (2014). An introduction to macroeconomics, second edition, Ibadan: Evans Brothers (Nigeria Publishers) Limited

xxii. Onipede, D., \& Ayodeji, E. A. (2005). Economics (A Complete Text on 'O' \& 'A' Level Economics), Ibadan: Kins Publishers Limited

xxiii. Owolabi, A. U.,\& Adegbite, T. A. (2014). Impact of monetary policy on industrial growth in Nigeria. International Journal of Academic Research in Business and Social Sciences, $4 \quad$ (1), 18-31

xxiv. Shaw, E. (1973). Financial deepening in economic development. London: Oxford University Press

xxv. Solomon, A. Z., \& Olaleye, M. O. (2001). An introduction to macroeconomics, first edition. Osogbo: Mighty Babs Productions.

xxvi. Sulaiman, L., \& Migiro, S. (2014) The nexus between monetary policy and economic growth inNigeria: A causality test. Public and Municipal Finance, 3, 1-6

xxvii. Uzoma, O.A., Bowale, E.I., \&Ogundipe, A.A. (2017). Monetary policy shocks and manufacturing sector in Nigeria. A structural VAR approach. International Journal of Internet Banking and Commerce,22(8), 1-22 